\title{
KELEMBAGAAN PETANI DAN SOSIAL EKONOMI TERHADAP PARTISIPASI ANGGOTA KELOMPOK DALAM PROGRAM PENGEMBANGAN USAHA PANGAN MASYARAKAT (PUPM)
}

\section{FARMERS AND ECONOMIC SOCIAL INSTITUTIONS ON THE PARTICIPATION OF GROUP MEMBERS IN THE COMMUNITY FOOD DEVELOPMENT PROGRAM (PUPM)}

\author{
Euis Dasipah, Karyana K.S., Rina Ridiawaty \\ Program Studi Agribisnis, Fakultas Pertanian, \\ Universitas Winaya Mukti Bandung \\ *Email: euisdasipah@gmail.com \\ (Diterima 13-04-2021; Disetujui 03-06-2021)
}

\begin{abstract}
ABSTRAK
Partisipasi masyarakat penting dalam keberhasilan implementasi program Pengembangan Usaha Pangan Masyarakat (PUPM). Penelitian ini bertujuan untuk (1) Menilai pengaruh manajemen kelompok terhadap partisipasi anggota kelompok tani dalam kegiatan program; (2) Menilai pengaruh sosial ekonomi terhadap partisipasi anggota kelompok tani dalam kegiatan program; (3) Menilai pengaruh kelembagaan dan sosial ekonomi petani terhadap partisipasi anggota kelompok tani dalam keberhasilan program Pengembangan Usaha Pangan Masyarakat (PUPM). Metode penelitian Analisis Deskriptif. Data dikumpulkan dengan teknik pengambilan sampel. Metode pengambilan sampel yang digunakan adalah simple random sampling. Populasi penelitian berjumlah 138, dengan sampel penelitian 102 orang. Pemilihan kabupaten sampel dilakukan dengan sengaja karena kecamatan adalah lokasi yang menerima program Pengembangan Usaha Pangan Masyarakat (PUPM). Hasil penelitian menunjukkan bahwa Faktor Kelembagaan petani memiliki kontribusi positif dan signifikan terhadap tingkat partisipasi anggota kelompok tani dalam program Pengembangan Usaha Pangan Masyarakat. Faktor sosial ekonomi petani memiliki kontribusi positif dan signifikan terhadap tingkat partisipasi anggota kelompok tani dalam program Pengembangan Usaha Pangan Masyarakat (PUMP). Secara simultan Lembaga tani dan sosial ekonomi petani berkontribusi signifikan terhadap partisipasi anggota kelompok tani dalam program Pengembangan Usaha Pangan Masyarakat (PUMP).
\end{abstract}

Kata kunci : Pengaruh Petani, Sosial Ekonomi, Partisipasi

\section{ABSTRACT}

Community participation is important in the successful implementation of the Community Food Business Development (PUPM) program. This study aims to (1) Assess the effect of group management on the participation of farmer group members in program activities; (2) Assessing the socioeconomic influence on the participation of farmer group members in program activities; (3) Assess the influence of farmer institutions and socioeconomic on the participation of farmer group members in the success of the Community Food Business Development (PUPM) program. Descriptive Analysis research methods. Data collected by sampling technique. The sampling method used was simple random sampling. The study population numbered 138, with a research sample of 102 people. The selection of sample districts is done deliberately because the kecamatan is a location that receives a Community Food Business Development (PUPM) program. The results showed that the Institutional Factors of farmers had a positive and significant contribution to the level of participation of farmer group members in the Community Food Business Development (PUMP) program. Socio-economic factors of farmers have a positive and significant contribution to the level of participation of farmer group members in the Community Food Business Development (PUMP) program. Simultaneously farmer Institution and farmer socioeconomic contributed significantly to the participation of farmer group members in the Community Food Business Development (PUMP) program.

Keywords: The Influence of Farmers, Economic Social, Participation 


\section{PENDAHULUAN}

Pembangunan pertanian merupakan bagian yang terintegral dari pembangunan ekonomi yang dilakukan oleh bangsa Indonesia. Pembangunan sebagai proses perubahan, menurut Goulet dalam Todaro (1994), mengandung nilai-nilai: (a) nafkah hidup, dalam arti kemampuan masyarakat untuk memenuhi atau mencukupi kebutuhankebutuhan dasar (basic needs) yang mencakup ; pangan, sandang, perumahan, kesehatan, pendidikan dasar dan perlindungan; (b) peningkatan harga diri, dalam arti berkembangnya rasa diri untuk dapat hidup mandiri terlepas dari penindasan dan tidak dimanfaatkan oleh pihak lain hanya untuk kepentingan mereka; dan (c) diperolehnya kebebasan untuk memilih alternatif-alternatif yang dapat dilakukan untuk mewujudkan perbaikan mutu hidup atau kesejahteraan seara terus menerus bagi setiap individu maupun warga masyarakatnya.

Kedaulatan Pangan merupakan salah satu agenda penting pembangunan nasional. Arah kebijakan umum kedaulatan pangan dalam RPJMN 20152019 adalah pemantapan ketahanan pangan menuju kemandirian pangan dengan peningkatan produksi pangan pokok, stabilisasi harga bahan pangan, terjaminnya bahan pangan yang aman dan berkualitas dengan nilai gizi yang meningkat serta meningkatnya kesejahteraan pelaku usaha pangan (Badan Ketahanan Pangan 2019).

$$
\text { Menurut Irnad (2018), }
$$

Pengembangan Usaha Pangan atau PUPM adalah kegiatan memberdayakan lembaga usaha pangan masyarakat atau gabungan kelompok tani dalam melayani Toko Tani Indonesia untuk menjaga stabilitas pasokan dan harga pangan. Program Pengembangan Usaha Pangan Masyarakat (PUPM) yaitu; menyerap produk pertanian nasional dengan harga yang layak dan menguntungkan petani khususnya pada bahan pangan pokok, serta mendukung stabilisasi pasokan dan harga pangan, dan memberikan kemudahan akses konsumen/masyarakat terhadap bahan pangan pokok, dengan harga yang terjangkau dan wajar.

Program PUPM merupakan suatu program yang dibentuk oleh pemerintah melalui Kementerian Pertanian dan Badan Ketahanan Pangan dalam rangka menjaga stabilitas harga baik di tingkat produsen (petani) dan di tingkat konsumen (Zakia, 2017).

Faktor-faktor yang berhubungan nyata dengat tingkat partisipasi petani pada Pogram PUPM ialah tingkat 
pengetahuan petani tentang Program PUPM, frekuensi komunikasi petani pada Program PUPM, dan kekosmopolitan petani, sedangkan faktor yang tidak berhubungan nyata dengan tingkat partisipasi petani pada Pogram PUPM ialah jumlah anggota keluarga dan motivasi (Resti Anggraini dkk, 2019).

Pembangunan masyarakat mencakup aneka ragam kegiatan yang dimaksudkan untuk meningkatkan taraf hidup masyarakat. Proses yang komplek ini terdiri atas dua unsur pokok yaitu : (1) partisipasi masyarakat dalam usahanya untuk meningkatkan taraf hidup mereka dengan mengandalkan sedapat mungkin pada inisiatif mereka sendiri dan (2) penyediaan keperluan teknis dan pelayanan-pelayanan lain sebagai cara untuk memperkuat inisiatif, kemandirian, dan gotong royong yang membuat pembangunan menjadi lebih efektif (Slamet, 1994).

Kesejahteraan petani merupakan tantangan pemerintah daerah di era otonomi. Otonomi daerah hendaknya mendekatkan pemerintah kepada petani, menunjukkan kepedulian kepada petani dan pertanian, mempercepat pemecahan masalah petani dan pertanian. Dengan otonomi daerah pemda memiliki posisi strategis dengan keleluasaan untuk membuat kebijakan dan program pembangunan pertanian yang semakin fokus, bisa menemukan komoditas unggulan sesuai potensi lokal, dan menemukan beragam upaya inovasi nilai tambah produk pertanian. Dengan otonomi, idealnya permasalahan yang dihadapi petani dan pertanian dengan cepat diketahui dan diberikan solusi yang memadai (Sunarti dan Khomsan, 2006).

$$
\text { Menurut Apriyani }
$$

Partisipasi seseorang dalam suatu kegiatan dipengaruhi oleh beberapa faktor yang disebut karakteristik petani, yang meliputi pendidikan non formal, pendapatan, pengalaman, keaktifan keanggotaan petani, luas penguasaan lahan, manajemen kelompok, budaya organisasi dan peran pemerintah.

Kapasitas atau kemampuan petani merupakan salah satu prasyarat bagi petani untuk berpartisipasi dalam pembangunan pertanian. Hal tersebut dapat dilakukan melalui pengembangan kelembagaan.

Pengembangan kelembagaan bagi masyarakat petani dianggap penting karena beberapa alasan. Pertama, banyak masalah pertanian yang hanya dapat dipecahkan oleh suatu lembaga petani. Kedua, organisasi masyarakat memberikan kelanggengan atau kontinuitas pada usaha-usaha untuk 
menyebarkan dan mengembangkan teknologi, atau pengetahuan teknis kepada masyarakat. Ketiga, untuk menyiapkan masyarakat agar mampu bersaing dalam struktur ekonomi yang terbuka (Bunch, 1991).

Hasil dari beberapa penelitian menunjukkan bahwa kebanyakan petani di Indonesia adalah "peasant" yang memiliki karakteristik khas. Peasant adalah petani kecil yang lahan pertaniannya sempit dengan hasil usahatani yang sebagian besar untuk keperluan keluarga, bersifat tradisional. Sedangkan, farmer adalah petani pengusaha yang menjalankan usaha tani secara perusahaan, dan biasanya memiliki lahan luas karena hasil pertaniannya untuk konsumsi pasar (Warsana, 2008).

Petani yang berdaya, menurut Susetiawan (2000), adalah petani yang secara politik dapat mengartikulasikan (menyampaikan

perwujudan) kepentingannya, secara ekonomi dapat melakukan proses tawar menawar dengan pihak lain dalam kegiatan ekonomi, secara sosial dapat mengelola mengatur komunitas dan mengambil keputusan secara mandiri, dan secara budaya diakui eksistensinya.

Kecamatan Tanjungmedar Kabupaten Sumedang merupakan salah satu kecamatan yang ditunjuk oleh Pemerintah Kabuaten Sumedang dalam mengikuti Program Pengembangan Usaha Pangan Masyarakat (PUPM). Sasaran kelompok kegiatan tersebut terdiri atas Kelompok Tani Sehat dan Kelompok Tani Mekar Jaya 2, alasan pemilihan kelompok tani ini oleh Dinas Pertanian dan Ketahanan Kabupaten Sumedang karena dianggap mampu dan memenuhi syarat dari program tersebut, syarat dari program Pengembangan Usaha Pangan Masyarakat yaitu Gapoktan/ poktan yang telah memiliki Rice Milling Unit (unit penggilingan padi) secara mandiri. Kecamatan Tanjungmedar juga merupakan kecamatan dengan areal yang cukup luas dan produksi yang cukup tinggi dengan sebagian besar masyarakatnya bekerja di sektor pertanian, sehingga termasuk sebagai kecamatan pemasok beras di Kabupaten Sumedang.

Tujuan penelitian ini adalah untuk mengetahui dan mempelajari: pengaruh manajemen terhadap partisipasi anggota kelompok tani pada kegiatan program Pengembangan Usaha Pangan Masyarakat (PUPM) di Kecamatan Tanjungmedar Kabupaten Sumedang; (2) pengaruh sosial ekonomi terhadap partisipasi petani anggota kelompok 
dalam keberhasilan program

Pengembangan Usaha Pangan

Masyarakat (PUPM). (3) pengaruh

kelembagaan petani dan sosial ekonomi, terhadap partisipasi petani anggota kelompok dalam keberhasilan program Pengembangan Usaha Pangan Masyarakat (PUPM) di Kecamatan Tanjungmedar Kabupaten Sumedang melalui partisipasi anggota kelompok tani

\section{METODE PENELITIAN}

Daerah penelitian ditentukan secara sengaja (Purposive Method) yaitu di Kecamatan Tanjungmedar Kabupaten Sumedang. Metode penelitian Deskriptif Analisis. Data di kumpulkan dengan teknik penarikan contoh. Metode penarikan contoh yang digunakan acak sederhana (simple random sampling). Populasi penelitian berjumlah 138, dengan Sampel penelitian sebanyak 102 orang. Pemilihan sampel wilayah kecamatan dilakukan secara sengaja karena kecamatan tersebut merupakan lokasi yang mendapat program kegiatan Pengembangan Usaha Pangan Masyarakat (PUPM).

Metode pengumpulan data yang digunakan adalah metode wawancara terstruktur, kepustakaan dan dokumen.
Metode statistik yang digunakan untuk menganalisis Kelembagaan Petani dan Sosial Ekonomi Petani terhadap Partisipasi Petani Anggota Kelompok dalam Program Pengembangan Usaha Pangan Masyarakat (PUPM) di Kecamatan Tanjungmedar Kabupaten Sumedang menggunakan analisis jalur (Path Analysis), sehingga terlihat hubungan kausalitas Kelembagaan Petani $\left(\mathrm{X}_{1}\right)$ dan Sosial Ekonomi Petani $\left(\mathrm{X}_{2}\right)$ sebagai variabel independen terhadap Partisipasi Petani Anggota Kelompok dalam Program Pengembangan Usaha Pangan Masyarakat (PUPM) (Y) sebagai variabel dependen.

Data penelitian merupakan data skala ordinal, maka untuk memenuhi analisis regresi (analisis jalur) yang memerlukan paling tidak skala ukur interval, maka terlebih dahulu dilakukan teknik analisis untuk meningkatkan skala data dari ordinal menjadi interval digunakan Metode Succsessive Interval (MSI).

Obyek atau variabel pada penelitian ini terdapat 3 (tiga) buah yaitu Faktor Kelembagaan Petani, Faktor Sosial Ekonomi Petani dan Partisipasi Anggota Kelompok Tani dalam Program PUPM. Ketiganya merupakan variabel-variabel kualitatif dan diukur secara kuantitatif 
dengan menggunakan teknik scoring yaitu berupa data dengan skala ordinal. Tingkat pengukuran terhadap tiap item/indikator dari masing-masing variabel digunakan 4 (empat) tingkatan yaitu: sangat tinggi (4), tinggi (3), sedang (2), rendah (1). Untuk variabel Kelembagaan Petani, $\left(\mathrm{X}_{1}\right)$ terdapat 12 item, karenanya skor minimal adalah 12 dan maksimal adalah 48. Untuk variabel Sosial Ekonomi Petani $\left(\mathrm{X}_{2}\right)$ terdapat 6 item, Skor minimal 6 dan skor maks 24. Selanjutnya untuk variabel Partisipasi Petani anggota Kelompok Tani dalam Program PUPM (Y), terdapat 8 item karenanya skor minimal 8 dan maksimal 32.

Penentuan range skor berdasarkan nilai terbesar dan tertinggi pada setiap variabel. penentuan range skor masingmasing variabel dapat dilihat pada Tabel 1.

Tabel 1. Range Skor Variabel Penelitian

\begin{tabular}{llccc}
\hline & & \multicolumn{3}{c}{ Range Skor } \\
\cline { 3 - 5 } No & Kategori & $\begin{array}{c}\text { Kelem- } \\
\text { bagaan }\end{array}$ & $\begin{array}{c}\text { Sosial } \\
\text { Ekonomi }\end{array}$ & Partisipasi \\
\hline 1. & Rendah & $1-12$ & $1-6$ & $1-8$ \\
2. & Cukup & $13-24$ & $7-12$ & $9-16$ \\
& Tinggi & & & \\
3. & Tinggi & $25-36$ & $13-18$ & $17-24$ \\
4. & Sangat & $37-48$ & $19-24$ & $25-32$ \\
& Tinggi & & & \\
\hline
\end{tabular}

Untuk menganalisis hasil interval digunakan rumus menurut Rusidi (1992) sebagai berikut:
$i=\frac{S k t-S k r}{K}$

Dimana:

$\mathrm{i}=$ Interval

Skt = Skor kumulatif tertinggi

Skr $=$ Skor kumulatif rendah

$\mathrm{K}=$ Kriteria pengukuran

Kriteria yang digunakan sebagai berikut:

1. Apabila skor lebih dari pendapatan tertinggi $-\mathrm{n}$ termasuk pendapatan tertinggi.

2. Apabila skor lebih dari pendapatan tertinggi $-\mathrm{n}-\mathrm{n}$ sampai dengan pendapatan tertinggi $-\mathrm{n}$ termasuk pendapatan sedang.

3. Apabila skor kurang atau sama dengan pendapatan tertinggi $-\mathrm{n}-\mathrm{n}$ termasuk pendapatan rendah.

Untuk melihat Pengaruh kelembagaan Terhadap Partisipasi, Pengaruh Sosial Ekonomi Terhadap Partisipasi, dan Pengaruh kelembagaan dan social ekonomi Kelompok Tani terhadap partisipasi kelompok dalam program pengembangan usaha pangan masyarakat akan digunakan analisis jalur (path analisis).

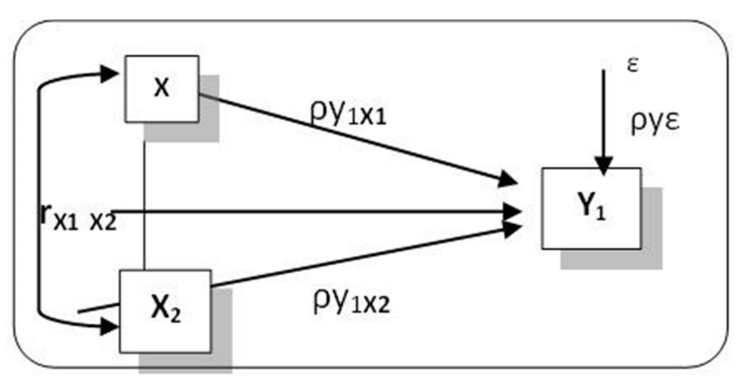

Gambar 1. Path Analysis 
Dari bagan jalur pada gambar dapat diartikan sebagai berikut, dimana hubungan antara Dari bagan jalur seperti pada gambar di atas dapat diartikan sebagai berikut, dimana hubungan antara $\mathrm{X}_{1}, \mathrm{X}_{2}$ terhadap $\mathrm{Y}$ merupakan hubungan kausal sedangkan hubungan antara $\mathrm{RX}_{2}$ ke $\mathrm{X}_{1}$ merupakan hubungan korelasi yang menunjukkan adanya hubungan variable independen $\mathrm{X}_{1}$ dan $\mathrm{X}_{2}$ dengan variabel dependen Y.

Berdasarkan pada diagram jalur hipotesis penelitian diatas, maka bentuk persamaan untuk diagram jalur tersebut adalah:

$$
Y=\rho y x_{1} X_{1}+\rho y x_{2} X_{2}+\rho y \varepsilon
$$

Pengujian hipotesis: Faktor kelembagaan petani dan Faktor sosial ekonomi petani berpengaruh terhadap Partisipasi. Selanjutnya untuk pengujian maka hipotesis penelitian tersebut ditransfomasi ke dalam hipotesis statistika.

\section{Hipotesis statistik:}

$\mathrm{H}_{1} \quad$ : Faktor kelembagaan petani dan faktor sosial ekonomi petani berpengaruh nyata terhadap Partisipasi petani anggota kelompok tani dalam program PUPM.

Ho : Faktor kelembagaan petani dan faktor sosial ekonomi petani berpengaruh tidak nyata terhadap Partisipasi petani anggota kelompok tani dalam program PUPM.

Statistika uji digunakan uji F dengan rumus:

$$
F_{h i t}=\frac{(n-k-1) R_{y x}^{2}}{k\left(1-R_{y x}^{2}\right)}
$$

$\mathrm{F}_{\text {tabel }}$ dengan $\mathrm{db}_{1}=\mathrm{k} ; \mathrm{db}_{2}=\mathrm{n}-\mathrm{k}-1$ dan taraf kesalahan $\alpha=5 \%$, diperoleh dari Tabel F untuk $\mathrm{F}(0, \mathrm{k}: \mathrm{db} 1 ; \mathrm{db} 2)$

Kaidah keputusan:

- Jika $\quad F_{\text {hit }}>F_{\text {tabel : }}$ maka tolak Ho atau terima $\mathrm{H} 1$ yang berarti bahwa faktor kelembagaan petani dan faktor sosial ekonomi petani berpengaruh nyata terhadap Partisipasi petani anggota kelompok tani dalam program PUPM.

- Jika $\mathrm{F}_{\text {hit }}<\mathrm{F}_{\text {tabel : }}$ maka terima Ho atau tolak H1 yang berarti bahwa faktor kelembagaan petani dan faktor sosial ekonomi petani berpengaruh tidak nyata terhadap Partisipasi petani anggota kelompok tani dalam program PUPM.

\section{Pengujian Secara Parsial (Individu)}

Selanjutnya apabila pengujian secara serempak terbukti nyata maka dilanjutkan untuk melihat sejauhmana pengaruh masing-masing variabel bebas. Hipotesis statistika yang diuji: Ho $: \mathrm{py}_{\mathrm{i}} \mathrm{x}_{\mathrm{i}}=0$ lawan 
Hi : $\mathrm{py}_{\mathrm{i}} \mathrm{x}_{\mathrm{i}} \neq 0$

dimana i adalah banyaknya variabel bebas (Xi) yang mempengaruhi Partisipasi petani anggota kelompok tani dalam program PUPM. $\left(\mathrm{Y}_{1}\right)$. Statistika uji yang digunakan adalah:

$$
\mathrm{t}_{\text {hit }}=\frac{\mathrm{bi}}{\mathrm{Sbi}}
$$

$\propto=$ tingkat kesalahan $5 \%$, atau selang kepercayaan $95 \%$.

$\mathrm{t}_{\text {tabel }}=\mathrm{t}_{(\propto / 2: \mathrm{n}-\mathrm{k})}$ atau $\mathrm{t}_{(0,05: \mathrm{n}-\mathrm{k})}$

Daerah kritis : $\mathrm{t}<\mathrm{t}(\propto / 2: \mathrm{n}-\mathrm{k})$ dan $\mathrm{t}>\mathrm{t}$ $(\propto / 2, \mathrm{n}-\mathrm{k})$

Kaidah keputusan:

- Jika $t_{\text {hit }}>t_{\text {tabel }}$ tolak Ho yang berarti bahwa masing-masing variabel bebas (Xi) berpengaruh nyata terhadap Partisipasi petani anggota kelompok tani dalam program PUPM. $\left(\mathrm{Y}_{1}\right)$.

- Jika $t_{\text {hit }} \leq t_{\text {tabel }}$ terima Ho yang berarti bahwa masing-masing variabel bebas (Xi) berpengaruh tidak nyata terhadap Partisipasi petani anggota kelompok tani dalam program PUPM. $\left(\mathrm{Y}_{1}\right)$.

\section{HASIL DAN PEMBAHASAN}

\section{A. Uji Validitas}

Setelah kuesioner terkumpul
selanjutnya data ditabulasi dan
dilaksanakan uji validitas. Uji validitas
menggunakan bantuan program statistical
product and service solution (SPSS) versi 16.0. Untuk menguji validitas alat ukur, terlebih dahulu dicari harga korelasi antara bagian-bagian dari alat ukur secara keseluruhan dengan cara mengkorelasikan setiap butir alat ukur dengan skor total yang merupakan jumlah tiap skor butir. pearson product moment. Apabila terdapat butir pertanyaan yang tidak valid, maka pertanyaan tersebut dihilangkan dan tidak digunakan lagi untuk proses selanjutnya. Dari hasil pengujian didapat bahwa nilai KMO sebesar 0,620. Nilai KMO $(0,620)>0,50$ artinya bahwa instrumen valid. Korelasi anti image menghasilkan korelasi yang cukup tinggi untuk masing-masing item, yaitu 0,590 untuk $X_{1}, 0,833$ untuk $X_{2}$ dan 0,575 untuk Y. Hal ini menyatakan bahwa semua item yang digunakan untuk mengukur konstruk kepuasan instrinsik memenuhi kriteria sebagai pembentuk konstruk. Dari hasil pengujian didapat bahwa nilai KMO sebesar 0,620. Nilai KMO $(0,620)>0,50$ artinya bahwa instrumen valid. Korelasi anti image menghasilkan korelasi yang cukup tinggi untuk masing-masing item, yaitu 0,590 untuk $X_{1}, 0,833$ untuk $X_{2}$ dan 0,575 untuk Y. Hal ini menyatakan bahwa semua item yang digunakan untuk mengukur konstruk kepuasan instrinsik memenuhi kriteria sebagai pembentuk konstruk. 
Dari hasil pengujian didapat bahwa nilai KMO sebesar 0,620. Nilai KMO $(0,620)>0,50$ artinya bahwa instrumen valid. Korelasi anti image menghasilkan korelasi yang cukup tinggi untuk masingmasing item, yaitu 0,590 untuk $\mathrm{X}_{1}, 0,833$ untuk $\mathrm{X}_{2}$ dan 0,575 untuk $\mathrm{Y}$. Hal ini menyatakan bahwa semua item yang digunakan untuk mengukur konstruk kepuasan instrinsik memenuhi kriteria sebagai pembentuk konstruk.

\section{B. Uji Reliabilitas}

Setelah dilakukan uji validitas terhadap semua variabel, maka selanjutnya dilakukan uji reliabilitas. Uji reliabilitas ini dilaksanakan dengan bantuan program SPPS untuk menentukan nilai alpha Conbach.

Dari hasil pengujian dapat diketahui bahwa nilai koefisien cronbach alpha adalah 0,821. Menurut Satori (2009), suatu instrumen penelitian mengindikasikan memiliki reliabilitas yang memadai jika koefisien alpha Cronbach lebih besar atau sama dengan 0,70 . Sementara hasil uji menunjukan koefisien alpha Cronbach sebesar 0,821, dengan demikian dapat disimpulkan bahwa variabel ini cukup reliabel.

\section{Deskripsi Variabel Penelitian}

Kelembagaan petani yang mempengaruhi tingkat partisipasi anggota kelompok tani pada Program Pengembangan Usaha Pangan Masyarakat (PUMP) meliputi;

a. Manajemen kelompok tani, yaitu kemampuan ketua kelompok tani dalam pengelolaan kelompok tani sebagai wadah petani;

b. Budaya organisasi, yaitu kebiasaan atau perilaku petani anggota kelompok tani dalam berorganisasi.

Hasil penelitian menunjukkan bahwa manajemen kelompok tani termasuk pada kategori tinggi $(53,07 \%)$. Hal ini didasari dengan tingkat pengetahuan anggota kelompok tani akan kelas kemampuan kelompok, fungsi dan peranan ketua, penilaian anggota terhadap kepemimpinan ketua kelompok tani, bahwa dengan kepercayaan anggota terhadap manajemen kelompok mereka akan meningkatkan kepercayaan akan manfaat berkelompok tani. Dengan demikian akan memacu tingkat partisipasi anggota kelompok tani dalam program PUMP dalam setiap kegiatan yang ada di kelompok tani. Hasil penelitian ini sesuai dengan pendapat Anwar (2013) bahwa kepercayaan akan menjadikan dasar pengetahuan seseorang 
dalam menentukan sikapnya terhadap suatu objek, kepercayaanlah yang menyederhanakan dan mengatur apa yang seseorang lihat dan temui.

Budaya organisasi adalah kebiasaan atau perilaku anggota kelompok dalam berorganisasi. Hal ini ditunjukkan dengan tingkat keaktifan dalam berorganisasi, mengetahui fungsi dan peranan organisasi, bagaimana sikap mereka terhadap kegiatan dan terhadap pembaharuan.

Hasil penelitian menunjukkan bahwa budaya organisasi termasuk kategori tinggi (46,93 \%). Tingginya komponen ini karena setiap anggota kelompok tani mempercayai kemampuan, peran dan fungsi kelompok tani dalam meningkatkan kesejahteraan petani. Komponen ini dapat dilihat dengan tingkat keaktifan anggota kelompok menghadiri setiap pertemuan, dan kebiasaan menerima pembaharuan/ inovasi.

Hasil penelitian menunjukkan bahwa sosial ekonomi anggota kelompok tani sebanyak 14 orang $(13,73 \%)$ dikategorikan sedang, 83 orang $(81,37 \%)$ kategori tinggi, dan sisanya sebanyak 5 orang $(4,90 \%)$ sangat tinggi.

Sosial ekonomi anggota kelompok tani pada penelitian ini dibagi menjadi 6 indikator, yaitu pengalaman berorganisasi, pengalaman berusaha tani, pendidikan non formal (khususnya intensitas mengikuti penyuluhan), luas lahan yang digarap, pendapatan, dan jumlah anggota keluarga yang menjadi tanggungan.

Berdasarkan hasil penelitian sebanyak 2 orang dari 102 orang responden $(1,96 \%)$ dikategorikan memiliki partisipasi yang tinggi, sedangkan sebanyak 44 orang (43,14\%) dikategorikan memiliki partisipasi yang sangat tinggi. Sebanyak 57 orang (54,90\%) dikategorikan memiliki partisipasi yang sedang.

Partisipasi anggota kelompok tani dalam program PUMP terdiri atas 4 indikator, meliputi partisipasi dalam perencanaan, pelaksanaan kegiatan, pemanfaatan hasil dan evaluasi kegiatan. Hasil perhitungan untuk variabel partisipasi anggota kelompok tani dalam program PUMP.

Dari hasil penelitian terlihat bahwa tingkat partisipasi anggota kelompok tani pada Program Pengembangan Usaha Pangan Masyarakat pada tahap perencanaan tergolong tinggi $(67,28 \%)$, sedangkan pada tahap pelaksanaan $(57,84 \%)$, pemanfaatan hasil $(61,70 \%)$ 
dan evaluasi $(60,54 \%)$ berada pada kategori sedang.

\section{Pengujian Hipotesis Penelitian}

Pengujian hipotesis pada penelitian ini dianalisis dengan menggunakan analisis jalur (Path Analysis). Teknik analisis jalur ini digunakan untuk menguji besarnya pengaruh langsung dan tidak langsung yang diwujudkan oleh koefisien jalur pada setiap diagram jalur dari hubungan kausal antar variabel Kelembagaan Petani $\left(\mathrm{X}_{1}\right), \quad$ Sosial Ekonomi $\left(\mathrm{X}_{2}\right)$ terhadap Partisipasi Petani Anggota Kelompok dalam Program PUPM (Y) dengan menggunakan bantuan program SPSS versi 16.

Dari hasil pengujian diperoleh $\mathrm{R}_{\text {square }}=0,743$ dan diperoleh nilai $\mathrm{F}$ sebesar 142.883 dengan nilai probabilitas $(\operatorname{sig})=0,000$. Karena nilai sig $<0,05$ maka Ho ditolak dan $\mathrm{H}_{1}$ diterima artinya pengujian secara individual dapat dilakukan.

Selanjutnya dilakukan pengujian sacara parsial (individual) pengaruh kelembagaan petani $\left(\mathrm{X}_{1}\right)$ terhadap partisipasi anggota kelompok tani dalam program PUMP (Y), pengaruh sosial ekonomi $\left(\mathrm{X}_{2}\right)$ terhadap partisipasi anggota kelompok tani dalam program PUMP (Y) serta pengaruh partisipasi anggota kelompok tani dalam program PUMP $\left(\mathrm{X}_{1}\right)$ dan sosial ekonomi $\left(\mathrm{X}_{2}\right)$ Terhadap partisipasi anggota kelompok tani dalam program PUMP (Y).

\section{Pengaruh kelembagaan petani terhadap partisipasi anggota kelompok tani dalam program PUMP}

Signifikan (sig) didapat nilai sig. 0,000 lebih kecil dari nilai probabilitas 0,05 . Karena $0,05>$ 0,000 maka Ho ditolak dan $\mathrm{H}_{1}$ diterima artinya koefisien analisis jalur signifikan, jadi kelembagaan petani tani berpengaruh terhadap partisipasi anggota kelompok tani dalam program PUMP. Hasil pengujian terlihat bahwa $\rho \mathrm{yx}_{1}=$ 0,760. Besarnya pengaruh kelembagaan petani $\left(\mathrm{X}_{1}\right)$ terhadap partisipasi anggota kelompok tani dalam program PUMP (Y) sebesar $0,760^{2}=0,5776$ atau $57,76 \%$.

2. Pengaruh sosial ekonomi terhadap partisipasi anggota kelompok tani dalam program PUMP

Signifikan (sig) didapat nilai sig. 0,000 lebih kecil dari nilai probabilitas 0,05 . Karena $0,05>$ 0,000 maka Ho ditolak dan $\mathrm{H}_{1}$ diterima artinya koefisien analisis jalur signifikan, sosial ekonomi berpengaruh terhadap partisipasi 
anggota kelompok tani dalam program PUMP. Hasil pengujian diperoleh $\rho x_{2}=0,188$. Besarnya pengaruh sosial ekonomi $\left(\mathrm{X}_{2}\right)$ terhadap partisipasi anggota kelompok tani dalam program PUMP (Y) sebesar $0,352^{2}=0,0353$ atau $3,53 \%$.

Hasil pengujian menunjukan bahwa pengaruh kelembagaan petani sebesar $57,76 \%$, sedangkan pengaruh sosial ekonomi sebesar 3,53\%. Ini membuktikan dugaan bahwa kelembagaan petani lebih berpengaruh terhadap partisipasi anggota kelompok tani dalam program PUMP dibanding sosial ekonomi. Hal tersebut dibuktikan dengan keaktifan anggota kelompok tani dalam melaksanakan kegiatan Program Pengembangan Usaha Pangan Masyarakat (PUPM).

3. Pengaruh kelembagaan petani dan sosial ekonomi terhadap partisipasi anggota kelompok tani dalam program PUMP

Hasil pengujian diperoleh nilai dapat dilihat $\mathrm{R}_{\mathrm{yx1 \times 2}}^{2}$ atau $\mathrm{R}_{\text {square }}$ sebesar 0,743 . Untuk mencari $\rho y \varepsilon$ ditentukan dengan rumus sebagai berikut:

$\rho y \varepsilon=1-\mathbf{R}^{2}=1-0,743=0,257$
Kerangka hubungan kausal empiris antara pengaruh kelembagaan petani $\left(\mathrm{X}_{1}\right)$ dan sosial ekonomi $\left(\mathrm{X}_{2}\right)$ terhadap partisipasi anggota kelompok tani dalam program PUMP (Y) disajikan memalui persamaan struktural sebagai berikut:

$Y=\rho y_{\mathrm{X} 1} \mathrm{X}_{1}+\rho \mathrm{y}_{\mathrm{X} 2} \mathrm{X}_{2}+\rho \mathrm{y} \varepsilon$

Maka:

$$
\begin{gathered}
Y=0,760 X_{1}+0,1_{188} X_{2} \\
+0,257 \varepsilon
\end{gathered}
$$

Kontribusi besarnya pengaruh kelembagaan petani $\left(\mathrm{X}_{1}\right)$ dan sosial ekonomi $\left(\mathrm{X}_{2}\right)$ terhadap partisipasi anggota kelompok tani dalam program PUMP (Y) sebesar $\mathrm{R}_{\text {square }}=$ $0,743=74,3 \%$, sisanya sebesar 0,257 atau $25,7 \%$ dipengaruhi oleh faktor lain yang tidak dapat dijelaskan dalam penelitian ini.

Dari penjelasan-penjelasan di atas dapat dibuat diagram jalur hubungan kausal empiris kelembagaan petani $\left(\mathrm{X}_{1}\right)$ dan social ekonomi $\left(\mathrm{X}_{2}\right)$ terhadap partisipasi anggota kelompok tani dalam program PUPM (Y) sebagaimana terlihat pada Gambar 2. 


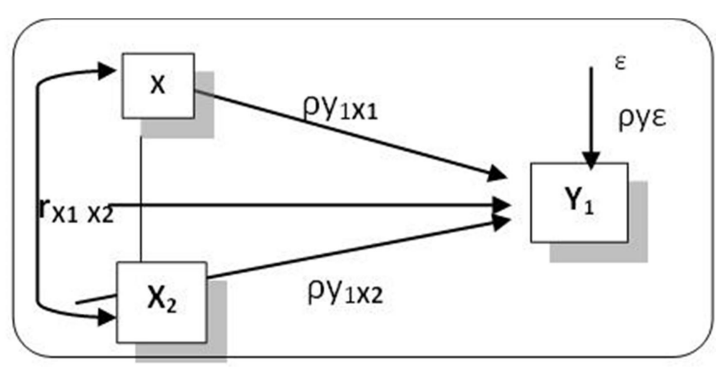

Gambar 2. Diagram Jalur

Berdasarkan hasil perhitungan analisis jalur struktur tersebut, maka memberikan informasi secara objektif sebagai berikut:

1. Pengaruh Langsung

- Kelembagaan petani $\left(X_{1}\right)$ yang diukur oleh partisipasi anggota kelompok tani dalam program PUMP (Y) memiliki kontribusi yang positif dan signifikan terhadap tinggi rendahnya partisipasi anggota kelompok tani dalam program PUMP (Y). Dengan demikian tinggi rendahnya partisipasi anggota kelompok tani dalam program PUMP (Y) dijelaskan oleh kelembagaan petani. Besarnya kontribusi kelembagaan yang secara langsung berkontribusi terhadap partisipasi anggota kelompok tani dalam program PUMP (Y) sebesar: $(0,760)^{2} \times 100 \%=57,76 \%$.

- Sosial ekonomi petani $\left(\mathrm{X}_{2}\right)$ yang diukur oleh partisipasi anggota kelompok tani dalam program PUMP (Y) memiliki kontribusi yang positif dan signifikan terhadap tinggi rendahnya partisipasi anggota kelompok tani dalam program PUMP (Y). Dengan demikian tinggi rendahnya partisipasi anggota kelompok tani dalam program PUMP (Y) dijelaskan oleh kelembagaan petani. Besarnya kontribusi Sosial ekonomi petani $\left(\mathrm{X}_{2}\right)$ yang secara langsung berkontribusi terhadap partisipasi anggota kelompok tani dalam program PUMP (Y) sebesar:

$(0,188)^{2} \times 100 \%=3,53 \%$.

2. Pengaruh Tidak Langsung

- Besarnya kontribusi kelembagaan yang secara tidak langsung berkontribusi terhadap partisipasi anggota kelompok tani dalam program PUMP (Y) melalui Sosial ekonomi petani $\left(\mathrm{X}_{2}\right)$ sebesar:

$0,760 \times 0,454 \times 0,188 \times 100 \%=$ $6,49 \%$.

- Besarnya kontribusi Sosial ekonomi petani $\left(\mathrm{X}_{2}\right)$ yang secara tidak langsung berkontribusi terhadap partisipasi anggota kelompok tani dalam program PUMP (Y) melalui Kelembagaan petani $\left(\mathrm{X}_{1}\right)$ sebesar:

$0,188 \times 0,454 \times 0,760 \times 100 \%=$ $6,49 \%$.

3. Secara simultan kelembagaan petani $\left(\mathrm{X}_{1}\right)$ dan sosial ekonomi petani $\left(\mathrm{X}_{2}\right)$ berkontribusi secara signifikan 
terhadap penerapan (adopsi) teknologi

$\left(\mathrm{Y}_{1}\right)$ sebesar Rsquare $=0,743=$
$74,3 \%$. Atau dapat dihitung sebagai berikut:

Pengaruh total $=\mathrm{X}_{1}$ : Pengaruh Langsung + Tidak Langsung

Pengaruh total $=\frac{\mathrm{X}_{2} \text { : Pengaruh Langsung }+ \text { Tidak Langsung }}{57,76 \%+6,49 \%}$

Total $=$ $\frac{3,53 \%+6,49 \%}{74,3 \%}+$

Sisanya yaitu sebesar $100-74,3 \%=$ 25,7 \% merupakan pengaruh yang datang dari faktor-faktor lain.

\section{KESIMPULAN DAN SARAN}

\section{Kesimpulan}

Berdasarkan hasil analisis dan pembahasan tentang Pengaruh Kelembagaan Petani dan Sosial Ekonomi dalam Program Pengembangan Usaha Pangan Masyarakat (PUPM) di Kecamatan Tanjungmedar Kabupaten Sumedang dapat disimpulkan sebagai berikut:

- Faktor kelembagaan petani memiliki kontribusi yang positif dan signifikan terhadap tinggi rendahnya partisipasi anggota kelompok tani dalam program Pengembangan Usaha Pangan Masyarakat (PUMP). Dengan demikian dari hasil penelitian terlihat bahwa tinggi rendahnya partisipasi anggota kelompok tani dalam program Pengembangan Usaha Pangan Masyarakat (PUMP) dipengaruhi secara langsung oleh faktor kelembagaan petani sebesar $57,8 \%$ maupun secara tidak langsung melalui sosial ekonomi sebesar 6,5\%. Sehingga faktor kelembagaan petani $\left(\mathrm{X}_{1}\right)$ berkontribusi sebesar $64,3 \%$ terhadap partisipasi anggota kelompok tani dalam program PUPM. - Faktor sosial ekonomi petani memiliki kontribusi yang positif dan signifikan terhadap tinggi rendahnya partisipasi anggota kelompok tani dalam program Pengembangan Usaha Pangan Masyarakat (PUMP). Dengan demikian dari hasil penelitian terlihat bahwa tinggi rendahnya partisipasi anggota kelompok tani dalam program Pengembangan Usaha Pangan Masyarakat (PUMP) dipengaruhi langsung oleh faktor sosial ekonomi petani sebesar 3,5\% maupun secara tidak langsung melalui faktor kelembagaan sebesar 6,5\%. Sehingga faktor sosial ekonomi petani berkontribusi sebesar 10,0\% terhadap partisipasi anggota kelompok tani dalam program PUPM. 
- Secara simultan kelembagaan petani dan sosial ekonomi petani berkontribusi secara signifikan terhadap partisipasi anggota kelompok tani dalam program Pengembangan Usaha Pangan Masyarakat (PUMP) sebesar 74,3\%, sisanya yaitu sebesar $100-74,3 \%=$ $25,7 \%$ merupakan pengaruh yang datang dari faktor-faktor lain.

\section{Saran}

Berdasarkan penelitian yang telah dilakukan, maka saran yang dapat disampaikan adalah:

1. Sosial ekonomi berpengaruh signifikan terhadap partisipasi anggota kelompok tani dalam program PUPM, namun ada 2 indikator yaitu luas lahan dan pendapatan dengan kriteria rendah. Anggota kelompok tani sebaiknya didorong untuk menerapkan teknologi dan intensifikasi usahatani sesuai dengan anjuran agar dapat meningkatkan produksi usahataninya dengan maksimal.

2. Partisipasi anggota kelompok tani pada kegiatan perencanaan, pelaksanaan, pemanfaatan hasil dan evaluasi rata-rata berada pada kategori sedang. Perlu adanya motivasi untuk dapat meningkatkan lagi keterlibatan anggota dalam jual beli gabah dan pemanfaatan hasil.

3. Pemerintah dalam hal ini instansi terkait diharapkan memberikan pembinaan yang berkelanjutan, seperti penyuluhan untuk meningkat pengetahuan dan kemampuan anggota kelompok dalam berusaha tani dan pengembangan program Pengembangan Usaha Pangan Masyarakat.

\section{DAFTAR PUSTAKA}

Badan Ketahanan Pangan. 2019. Pedoman Teknis Pengembangan Usaha Pangan Masyarakat Tahun 2019. Jakarta. Badan Ketahanan Pangan Kementerian Pertanian Republik Indonesia.

Bunch, Roland. 1991. Dua Tongkol Jagung: Pedoman Pengembangan Pertanian Berpangkal Pada Rakyat. Terjemahan oleh Ilya Moeliono. Yayasan Obor Indonesia. Jakarta.

E. Sunarti, A. Khomsan, 2006. Kesejahteraan Keluarga Petani Mengapa Sulit Diwujudkan?. Jurnal, Bogor:Institut Pertanian Bogor.

Irnad. 2018. Partisipasi Peserta Dan Kinerja Kelompok Tani Program Pengembangan Usaha Pangan Masyarakat (PUPM) (Studi Kasus Di Desa Ganesha Mukti, Kec. Muara Sugihan, Kab. Banyuasin, Provinsi Sumatera Selatan). Universitas Bengkulu. Bengkulu.

Rochana Apriyani. 2017. Partisipasi Petani Anggota Gapoktan dalam Program Pengembangan Usaha Pangan Masyarakat (PUPM) di Desa Mancasan Kecamatan Baki 
Kabupaten Sukoharjo. Universitas Sebelas Maret. Solo.

Resti Anggraini. 2019. Partisipasi Petani dan Keberhasilan Program Pengembangan Usaha Pangan Masyarakat (PUPM) di Kecamatan Palas Kabupaten Lampung Selatan. Jurnal Ilmu-ilmu Agribisnis. http://jurnal.fp.unila.ac.id/index.ph $\mathrm{p} / \mathrm{JIA} /$ article/view/3339.

Slamet, Y. 1994. Pembangunan Masyarakat Berwawasan Partisipatif. Surakarta: Sebelas Maret University.

Susetiawan, 2000. Perubahan Paradigma Pembangunan. Bahan Pembelajaran TOT Pembaharuan Kebijakan Pengelolaan Irigasi 17-23 November 2000.

Todaro, Michael P. 1994. Pembangunan Ekonomi di Dunia Ketiga Jilid I Edisi Keempat. Terjemahan. Penerbit Erlangga. Jakarta.
Warsana, SP, Strategi Melakukan Penyuluhan Pertanian untuk Petani "Kecil", 2008, Dalam: http://www.google.com/url?q=http: //www.litbang.deptan. go.id/artikel/one/202/pdf/Strategi\% 2520Melakukan\%2520Penyuluhan $\% 2520$ Pertanian\%2520untuk\%252 0Petani\%2520\%2522kecil\%2522.p $\mathrm{df} \& \mathrm{sa}=\mathrm{U} \& \mathrm{ei}=65 \mathrm{dIUZztKYrUrQeo}$ roHoCQ\&ved=0CBoQFjAA\&usg= AFQjCNHYaZ4auGQCWtwU41n DelB-Qe47wg

Zakia, Azaria (2017) Pola Komunikasi Penyuluh Pendamping Pada Program Pengembangan Usaha Pangan Masyarakat (PUPM) Melalui Kegiatan Toko Tani Indonesia (TTI) Di Gapoktan Tawang Jaya Mulya Abadi. Sarjana Tesis, Universitas Brawijaya. 